\title{
KARAKTERISTIK GEOKIMIA MANIFESTASI PANAS BUMI DAERAH SAMPURAGA, KABUPATEN MANDAILING NATAL, SUMATERA UTARA
}

\author{
Oleh: \\ *Dedi Kusnadi, ${ }^{* *}$ Nova Novelyarisyanti, ${ }^{* *}$ Rizka Novianda. \\ *Pusat Sumber Daya Geologi, \\ Jl. Soekarno Hatta No. 444 Bandung 40254 \\ **Fakultas Teknik Geologi, Universitas Padjadjaran, \\ Jl. Raya Bandung-Sumedang Km.21 Jatinangor
}

\section{SARI}

Penyelidikan dilakukan di daerah Sampuraga, Kabupaten Mandailing Natal, Provinsi Sumatera Utara. Di daerah tersebut ditemukan dua sumber mata air panas berdekatan dengan derajat keasaman $(\mathrm{pH})$ yang berbeda. Penyelidikan yang dilakukan meliputi pengukuran $\mathrm{pH}$, suhu, debit, daya hantar listrik, dan luas manisfestasi mata air panas. Dilakukan juga analisis geokimia air seperti anion, kation, dan isotop terhadap conto lapangan di laboratorium serta membandingkan reaksi kimia yang terjadi antara air panas ber-pH asam dengan netral.

Dari beberapa mata air panas bertemperatur tinggi yang ada di Sampuraga, suhu tertinggi terdapat di lokasi Sampuraga 2 yaitu $100,8^{\circ} \mathrm{C}$. pH air panas di lokasi ini berkisar dari asam sampai netral dengan debit cukup besar (1- 4 l/detik). pH dan temperatur berperan dalam mekanisme reaksi kimia yang terjadi. Berdasarkan pendugaan geotermometer air NaK didapatkan perkiraan temperatur reservoir sebesar $233^{\circ} \mathrm{C}$ yang termasuk ke dalam temperatur tinggi.

Kata kunci : air klorida, derajat keasaman, manifestasi panas bumi, sinter karbonat, temperatur tinggi.

\section{ABSTRACT}

The object of this research is hotspring located in Sampuraga area, Mandailing Natal Regency, North Sumatera Province. This research is conducted due to the fact that there are two hotspring with different $\mathrm{pH}$ in closed distance. Fieldwork consist of measuring $\mathrm{pH}$, temperature, water discharge, electric conductivity, and the wide area of each hotspring. Geochemical analyses such as anion, cation, and isotop were conducted to the samples of water. Comparison of chemical reaction between acid and neutral $\mathrm{pH}$ was also conducted in the laboratory.

Sampuraga hotspring number 1,2,3 and 4 show high temperature $\left(100.8^{\circ} \mathrm{C}\right)$, acid - neutral $p H$, and quite high water discharge $(1,2$ and $4 \mathrm{l} / \mathrm{s})$. $\mathrm{pH}$ and temperature control the mechanism of chemical reaction. Based on the NaK water geothermometer, the temperature of reservoir is estimated at $233^{\circ} \mathrm{C}$, which is classified as high temperature.

Keywords : acidity, carbonate sinter, chloride water, geothermal manifestations, high temperature.

\section{PENDAHULUAN}

Penyelidikan dilakukan di daerah Sampuraga, Kecamatan Longat, Kabupaten Mandailing Natal, Provinsi Sumatera Utara. Manifestasi panas bumi di daerah ini memiliki karakteristik yang berbeda-beda. Hal ini ditunjukkan dengan ditemukannya mata air panas ber-pH asam pada temperatur relatif tinggi $\left(97^{\circ} \mathrm{C}\right)$ dan mata air panas yang bertemperatur tinggi $\left(97-100.8^{\circ} \mathrm{C}\right)$ dengan $\mathrm{pH}$ asam - netral. Air panas disini termasuk dalam tipe air klorida dengan konsentrasi bikarbonat, kandungan $\mathrm{SO}_{4}$ yang cukup signifikan serta ditemukannya sinter karbonat.
Tujuan penyelidikan ini adalah untuk mengetahui karakteristik geokimia manifestasi panas bumi pada daerah Sampuraga.

\section{Geologi Daerah Penyelidikan}

Aldiss, dkk (1983) menyatakan bahwa secara regional daerah penyelidikan tersusun dari Formasi Silungkang dan Formasi Kuantan, batuan gunungapi, batuan terobosan, dan metasedimen yang berumur Paleozoik Kenozoik (Kuarter) . Mata air panas berada pada endapan aluvial dan diperkirakan muncul karena di bawahnya terdapat Batolit Panyambungan (Gambar 1). 


\section{MAKALAH ILMIAH}

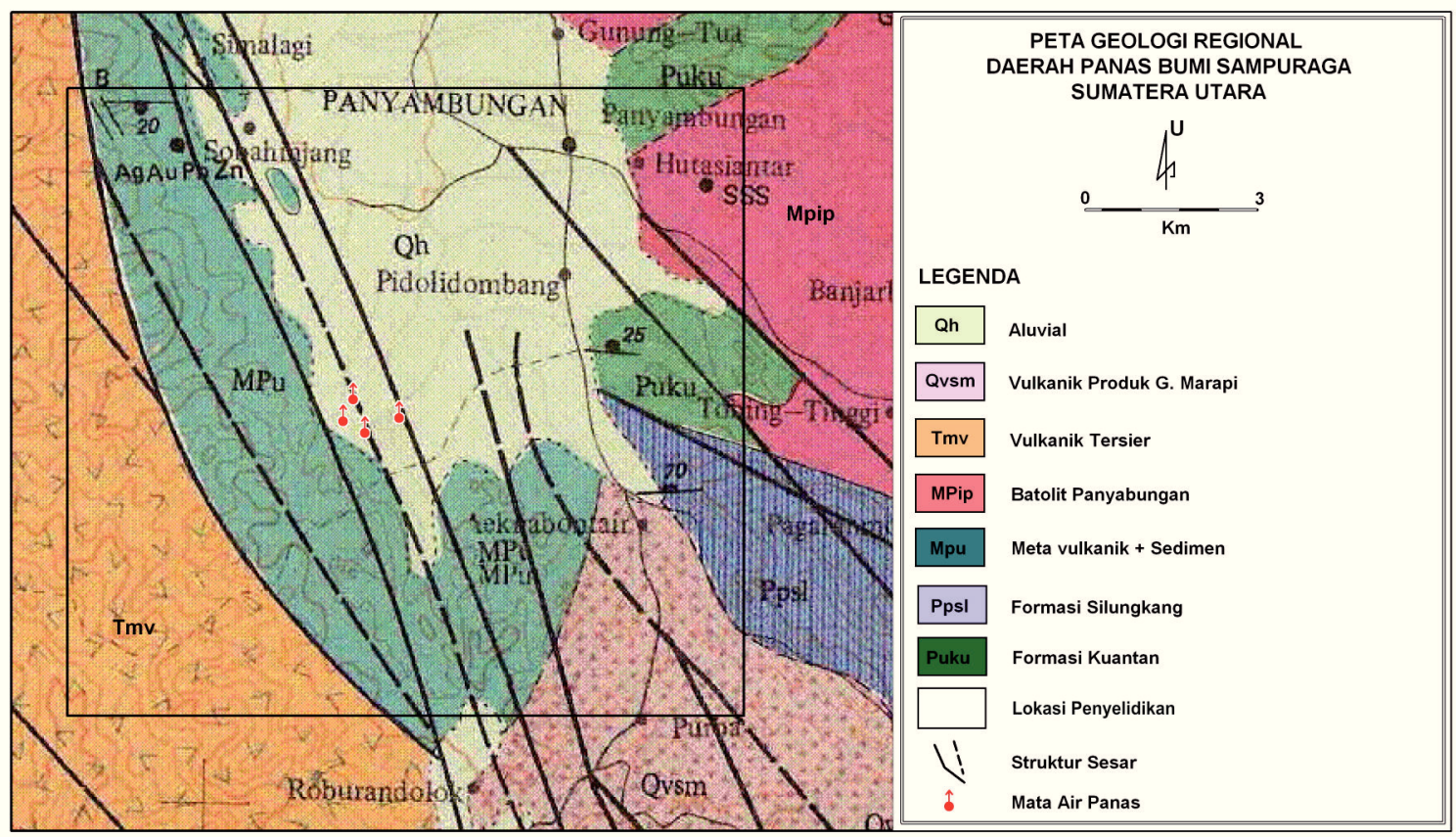

Gambar 1. Peta Geologi Regional Daerah Panas Bumi Sampuraga dan sekitarnya, Sumatera Utara (modifikasi dari Aldis dkk, 1983)

Struktur geologi pada daerah penyelidikan berarah baratlaut - tenggara. Analisis pada citra satelit menunjukkan bahwa struktur geologi di daerah penyelidikan didominasi sesar normal yang membentuk
Graben Panyambungan berarah barat lauttenggara serta sesar geser. Sesar normal ini diperkirakan memicu keluarnya sejumlah mata air panas di lokasi penyelidikan (Gambar 2).

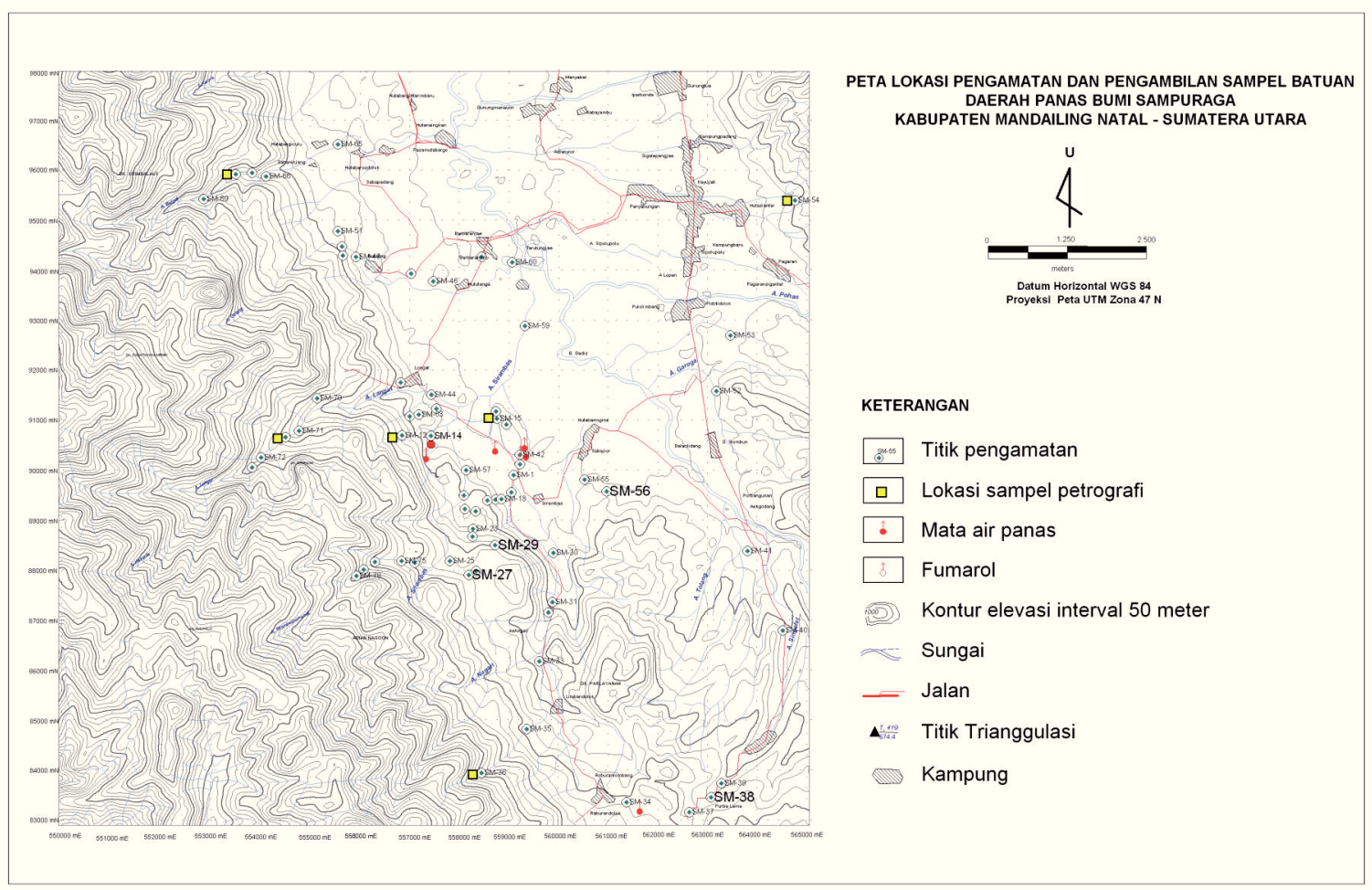

Gambar 2. Peta Lokasi Pengamatan dan Pengambilan Conto Batuan

Daerah Panas Bumi Sampuraga dan sekitarnya, Sumatera Utara 


\section{MAKALAH ILMIAH}

\section{Metode}

Metode yang dipakai dalam penyelidikan berupa pengukuran $\mathrm{pH}$, suhu, debit, daya hantar listrik, dan pengukuran luas manifestasi air panas Sampuraga. Selain itu dilakukan analisis geokimia air seperti anion, kation, dan isotop terhadap conto lapangan di laboratorium.
Dilakukan juga interpretasi data hasil analisis laboratorium, melalui perbandingan reaksi kimia yang melibatkan senyawa aluminaalumina dalam kondisi $\mathrm{pH}$ netral dan $\mathrm{pH}$ asam (Chen dan Brantley, 1997; Gigenbach, 1998; Grasby, dkk, 2000; Martin, dkk, 2000).

Tabel 1.

Data Lapangan Geokimia panas bumi

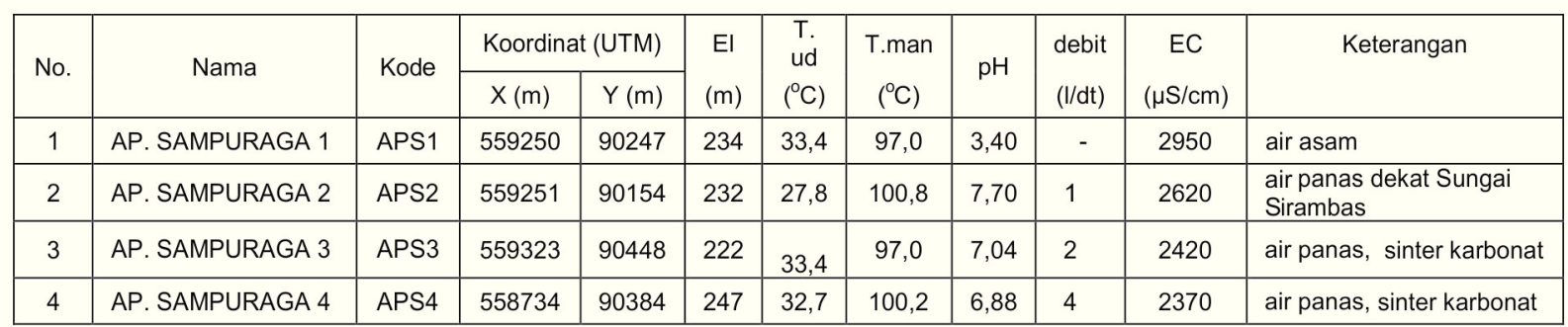

\section{HASIL}

\section{Manifestasi Panas Bumi}

Pengambilan conto air dilakukan pada empat titik yang berbeda (Tabel 1 ).

\section{Air Panas Sampuraga 1 (APS1),}

Lokasi ini berada di satuan batuan aliran piroklastik. Manifestasi dengan luas $3 \times 3 \mathrm{~m}^{2}$ ini berupa kolam air panas, dengan sedikit hembusan uap dan tercium gas $\mathrm{H}_{2} \mathrm{~S}$ (Gambar 3).

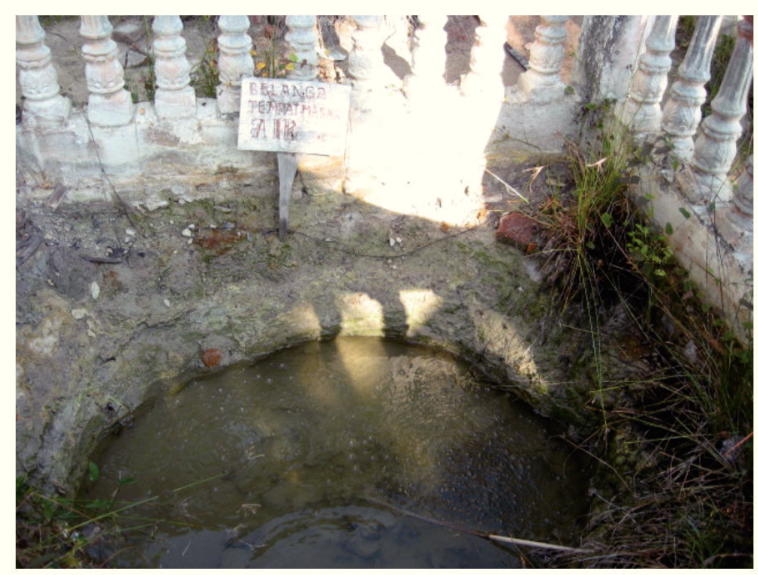

Gambar 3. Air Panas Sampuraga 1, pada batuan aliran piroklastik

\section{Air Panas Sampuraga 2 (APS2),}

Berjarak sekitar 100 meter ke arah timur dari lokasi APS1. Mata air panas ini muncul dari endapan aluvium yang terdapat di Sungai Sirambas. Manifestasi dengan luas $1 \times 1 \mathrm{~m}^{2}$ ini memiliki uap di permukaannya dan ditemukan pula sinter karbonat yang membungkus material endapan (Gambar 4).

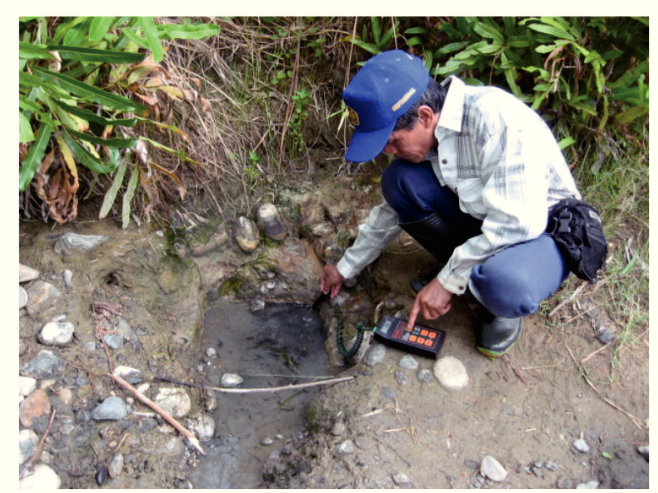

Gambar 4. Air Panas Sampuraga 2, pada pinggir sungai

\section{Air Panas Sampuraga 3 (APS3),}

Lokasi ini berjarak $300 \mathrm{~m}$ di sebelah utara APS1. Pada manifestasi dengan luas $3 \times 3$ $\mathrm{m}^{2}$ ini terdapat bualan dan uap air di permukaannya serta sinter karbonat di pinggirannya (Gambar 5).

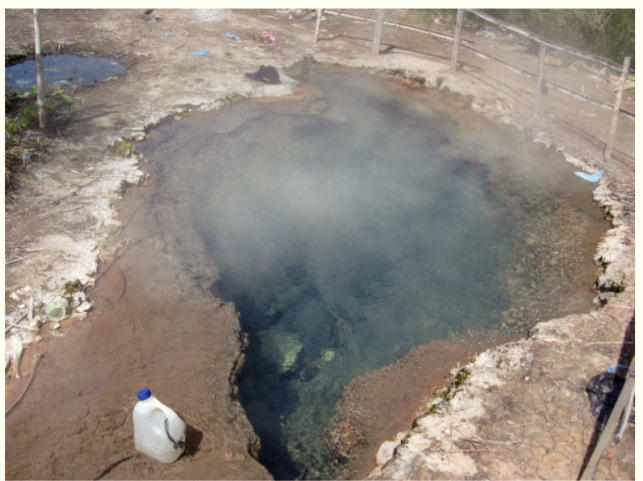

Gambar 5. Hembusan uap air, dan kolam air panas yang mengalir disertai sinter karbonat pada Air Panas Sampuraga 3 


\section{Air Panas Sampuraga 4 (APS4)}

Lokasi ini berjarak $500 \mathrm{~m}$ sebelah barat APS1 dan muncul pada batuan sedimen. Manifestasi dengan luas $2 \times 3 \mathrm{~m}^{2}$ ini memiliki bualan, uap di permukaan, dan sinter karbonat (Gambar 6).

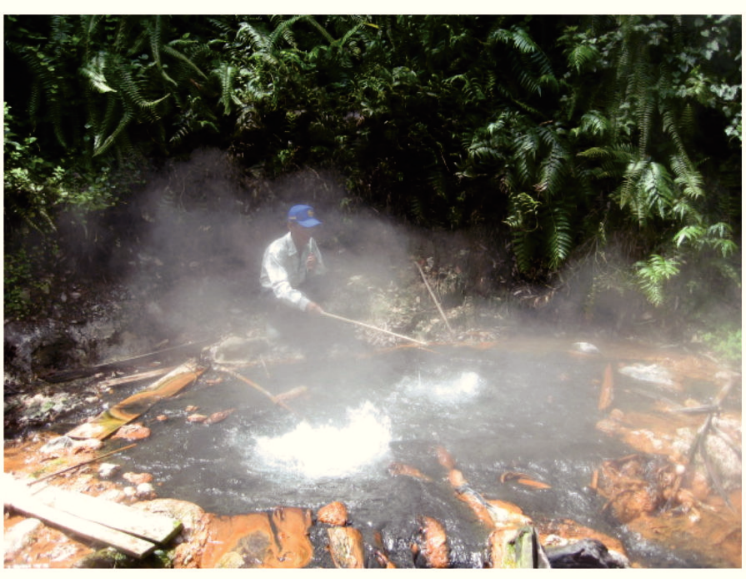

Gambar 6. Hembusan uap air, kolam air panas mendidih dan mengalir disertai sinter karbonat pada air panas manifestasi Sampuraga 4

\section{Hasil Analisis Geokimia Air Sampuraga}

Keakuratan proses analisis unsur utama kation dan anion dari mata air panas ditunjukkan dengan harga lon Balance (IB) kurang dari 5\% untuk semua conto air panas dan air dingin $\mathrm{pH}$ netral, serta lebih dari $5 \%$ untuk conto air yang asam. Hal ini mengindikasikan bahwa hasil analisis dapat digunakan dalam interpretasi geokimia selanjutnya. Untuk mengetahui karakteristik dan tipe air panas dari data yang diperoleh pada Tabel 2, dilakukan plotting komposisi kimia dari mata air panas pada diagram segitiga $\mathrm{Cl}-\mathrm{SO}_{4}-\mathrm{HCO}_{3}, \mathrm{Na}-\mathrm{K}-\mathrm{Mg}$, dan $\mathrm{Cl}-\mathrm{Li}-\mathrm{B}$ yang mengacu kepada Giggenbach (1988). Air Panas Sampuraga 1 memiliki pH rendah (asam) dengan tipe air sulfat, sedangkan Air Panas Sampuraga 2, 3, dan 4 memiliki pH netral bertipe air klorida (Gambar 7 ).

Berdasarkan diagram segitiga Na-K-Mg (Gambar 8), posisi mata air panas Sampuraga 2, 3 , dan 4 terletak pada partial equilibrium sebagai indikasi bahwa manifestasi yang muncul ke permukaan dipengaruhi oleh interaksi antara fluida dengan batuan dalam keadaan panas sebelum bercampur dengan air permukaan (meteoric water).

Tabel 2.

Data Hasil Analisis Geokimia Air

\begin{tabular}{|c|c|c|c|c|}
\hline \multirow{2}{*}{ Kode } & 1 & 2 & 3 & 4 \\
\cline { 2 - 5 } & APS1 & APS2 & APS3 & APS4 \\
\hline $\mathrm{SiO}_{2}(\mathrm{mg} / \mathrm{L})$ & 139,94 & 228,98 & 220,42 & 218,34 \\
\hline $\mathrm{Cl}$ & 70,36 & 597,75 & 580,16 & 562,57 \\
\hline $\mathrm{SO}_{4}$ & 1475,23 & 106,58 & 95,76 & 85,47 \\
\hline $\mathrm{HCO}_{3}$ & 0 & 195,26 & 211,83 & 216,93 \\
\hline $\mathrm{CO}_{3}$ & 0 & 0 & 0 & 0 \\
\hline $\mathrm{Al}$ & 53,48 & 0,18 & 0,00 & 0,00 \\
\hline $\mathrm{Fe}$ & 42,45 & 0,30, & 0,17 & 0,42 \\
\hline $\mathrm{Ca}$ & 179,50 & 24,76 & 24,90 & 31,83 \\
\hline $\mathrm{Mg}$ & 9,44 & 0,16 & 0,10 & 0,11 \\
\hline $\mathrm{Na}$ & 34,30 & 424,00 & 420,00 & 395,00 \\
\hline $\mathrm{K}$ & 11,00 & 42,50 & 42,80 & 39,80 \\
\hline $\mathrm{Li}$ & 0,30 & 2,67 & 2,54 & 2,52 \\
\hline $\mathrm{As}$ & 0,40 & 8,00 & 8,00 & 7,00 \\
\hline $\mathrm{NH}$ & 0,00 & 0,36 & 0,36 & 0,30 \\
\hline $\mathrm{B}$ & 0,98 & 27,77 & 28,31 & 26,24 \\
\hline $\mathrm{F}$ & 3,00 & 1,00 & 2,00 & 1,00 \\
\hline $\mathrm{meq}$ cat & 19,79 & 21,54 & 21,33 & 20,48 \\
\hline $\mathrm{meq}$ an. & 32,86 & 22,33 & 21,93 & 21,26 \\
\hline$\%$ IB & $-24,82$ & $-1,80$ & $-1,39$ & $-1,86$ \\
\hline
\end{tabular}




\section{MAKALAH ILMIAH}

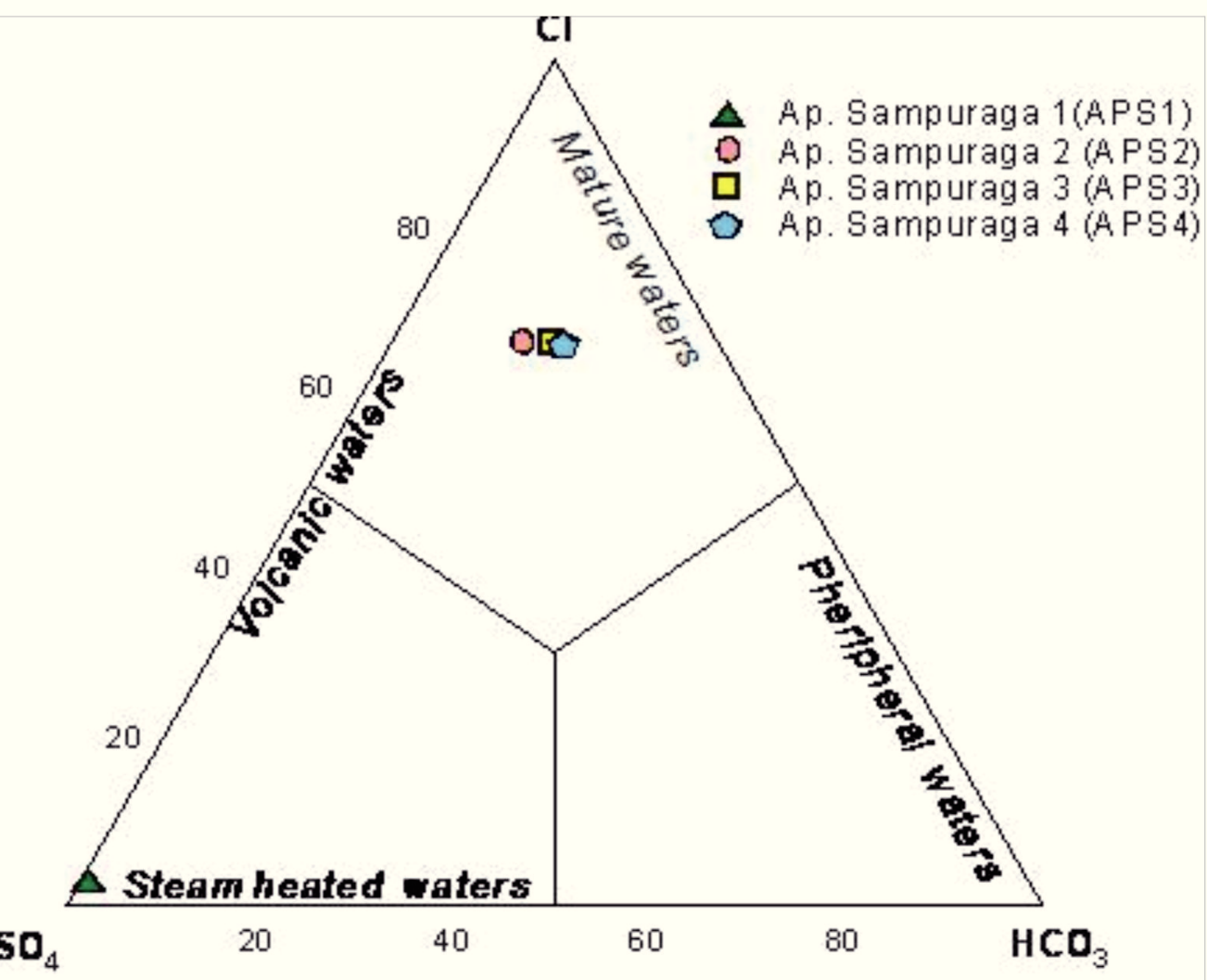

Gambar 7. Diagram segitiga tipe air panas daerah Panas Bumi Sampuraga, Kabupaten Mandailing Natal, Provinsi Sumatera Utara

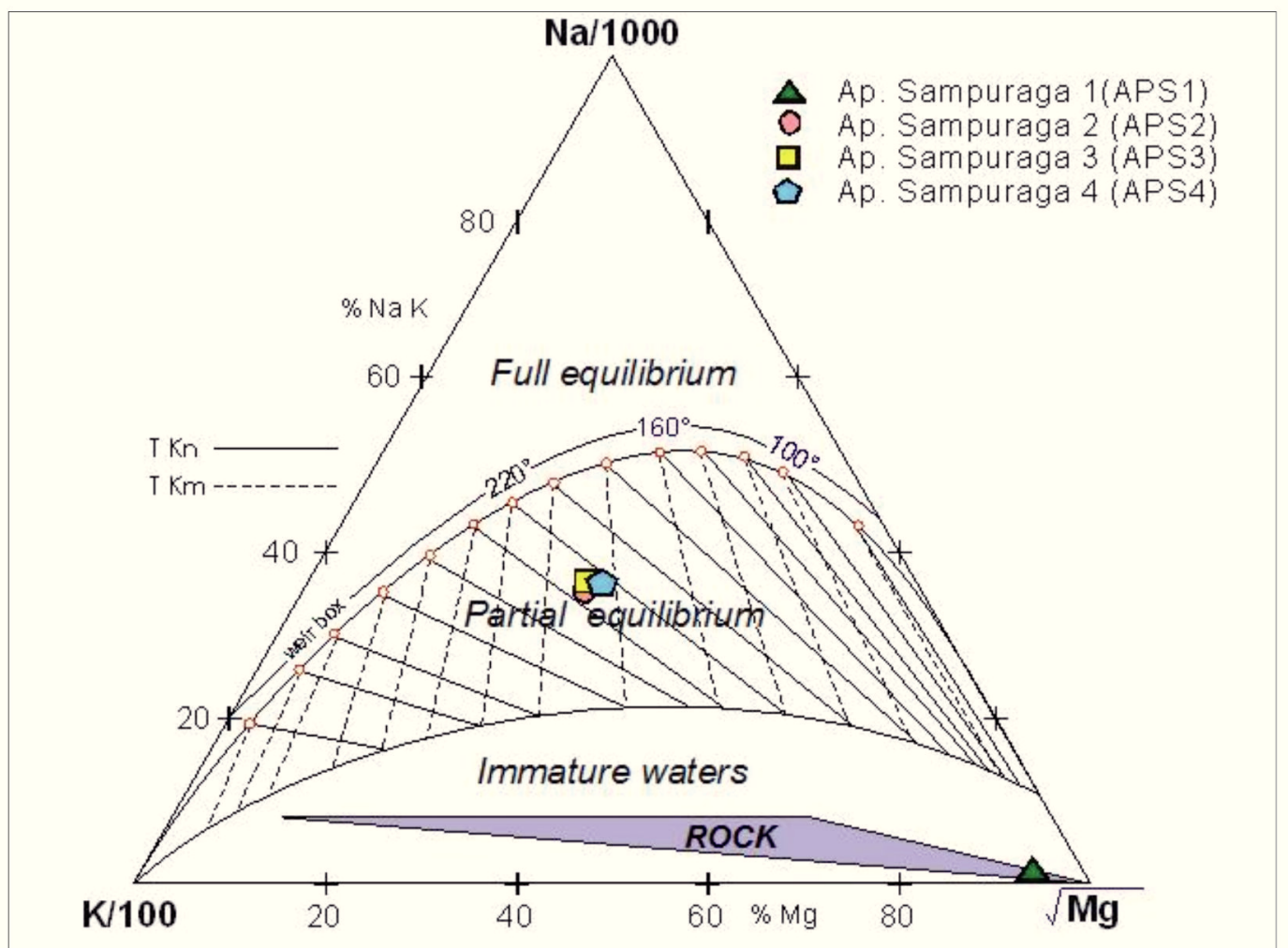

Gambar 8. Diagram segitiga kandungan $\mathrm{Na}, \mathrm{K}, \mathrm{Mg}$ daerah Panas Bumi Sampuraga, Kabupaten Mandailing Natal, Provinsi Sumatera Utara 


\section{MAKALAH ILMIAH}

Berdasarkan analisis pada Tabel 3, Nilai $\delta^{18} \mathrm{O}$ berkisar $-10,38$ sampai - 8,12 o/oo, sedangkan nilai $\delta D$ berkisar -66.7 sampai -52.5 o/oo. Nilai rasio dari conto air di plot pada grafik $\delta \mathrm{D}$ terhadap $\delta^{18} \mathrm{O}$, dengan garis air meteorik $\delta \mathrm{D}=$ $8 \delta^{18} \mathrm{O}+14$. Gambar 10 memperlihatkan posisi conto air panas Sampuraga 3 dan 4 terletak pada posisi sebelah kanan dari meteoric water line $\left({ }^{18} \mathrm{O}\right.$ shifted) yang signifikan sebagai indikasi pengayaan oksigen 18 dari air panas akibat reaksi substitusi oksigen 18 dari batuan dengan oksigen 16 dari fluida panas pada saat terjadi interaksi fluida panas dengan batuan sebelum muncul ke permukaan berupa mata air panas.

Sedangkan APS 1 terletak pada immature water sebagai indikasi pengaruh air permukaan lebih dominan pada pembentukan air panas tersebut. Berdasarkan diagram segi tiga Cl-Li-B (Gambar 9) posisi mata air panas tipe klorida terletak mengarah ke posisi tengah diagram.

Tabel 3.

Data Isotop $\delta D$ dan $\delta^{18} \mathrm{O}$ Air Panas Bumi

\begin{tabular}{|l|l|c|c|}
\hline No & Kode Conto & $\delta^{18} \mathrm{O}(\mathrm{oo} / \mathrm{o})$ & $\delta \mathrm{D}(\mathrm{oo} / \mathrm{o})$ \\
\hline 1 & AP. Sampuraga 3 (APS3) & $-9,43$ & $-65,0$ \\
\hline 2 & AP. Sampuraga 4 (APS4) & $-8,39$ & $-62,0$ \\
\hline
\end{tabular}

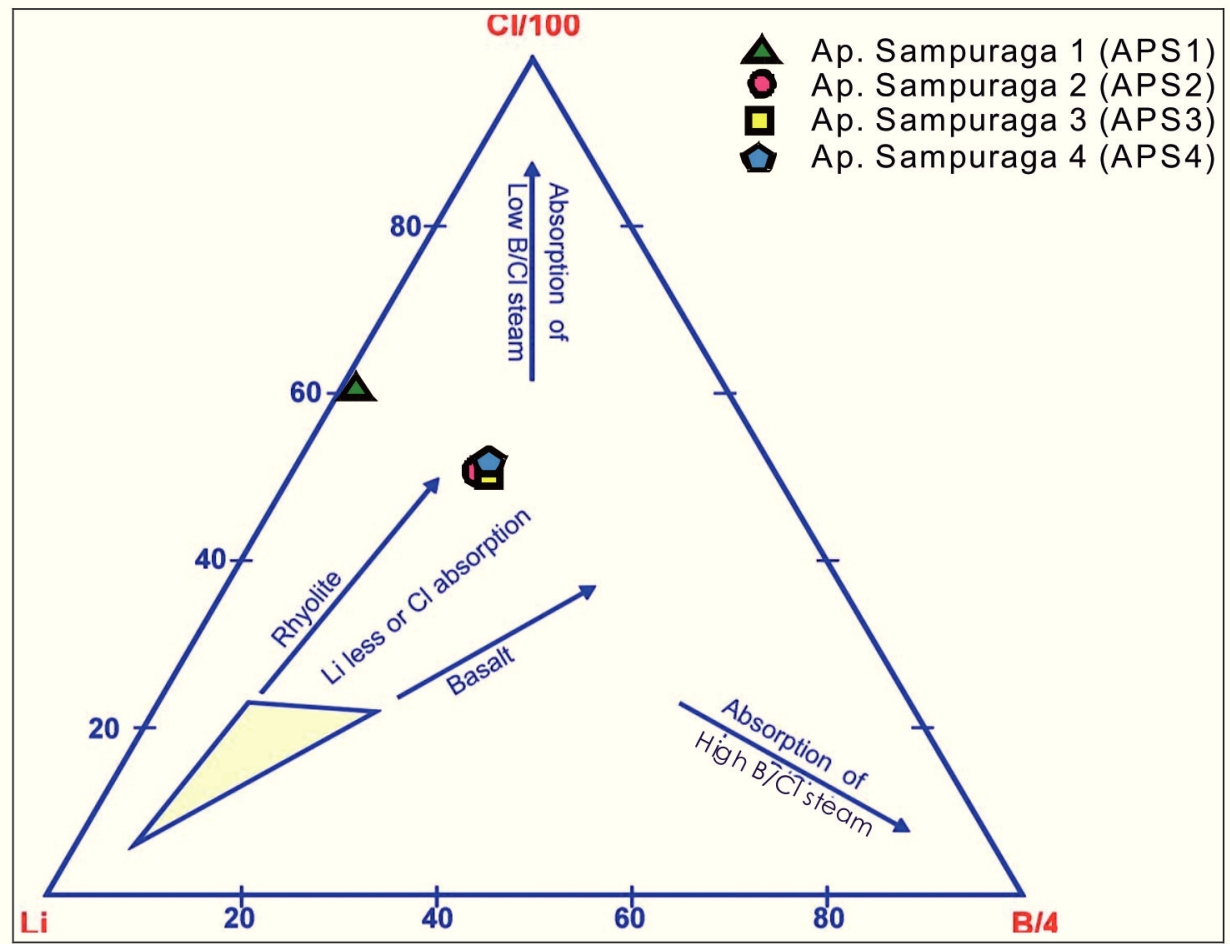

Gambar 9. Diagram segitiga kandungan $\mathrm{Cl}, \mathrm{Li}, \mathrm{B}$ daerah Panas Bumi Sampuraga, Kabupaten Mandailing Natal, Provinsi Sumatera Utara

\section{Pendugaan Suhu Bawah Permukaan}

Manifestasi panas bumi di daerah Sampuraga muncul pada elevasi 230 mdpl yang terdiri dari mata air panas asam bertemperatur $97^{\circ} \mathrm{C}$ dan mata air panas netral bertemperatur $97-$ $100,8^{\circ} \mathrm{C}$. Plotting pada diagram segitiga $\mathrm{Cl}-\mathrm{SO}_{4}^{-}$ $\mathrm{HCO}_{3}$ (Gambar 7) menunjukkan bahwa air dari mata air panas bersifat asam termasuk tipe air sulfat asam. dan air bersifat netral bertipe klorida dengan konsentrasi bikarbonat dan $\mathrm{SO}_{4}$ cukup signifikan. Air panas bersifat netral terletak pada partial equilibrium pada diagram $\mathrm{Na}-\mathrm{K}-\mathrm{Mg}$
(Gambar 8) dan terletak di tengah-tengah diagram segitiga Cl-Li-Boron. Hal ini mengindikasikan bahwa air panas berhubungan dengan reservoir panas bumi. Perhitungan suhu air memakai geotermometer $\mathrm{NaK}$ yang mengacu kepada Giggenbach, (1988), melalui persamaan $\mathrm{T}^{\circ} \mathrm{C}=[1390 /((\log \mathrm{Na} / \mathrm{K}+1,75]-273$ dengan hasil akhir $233^{\circ} \mathrm{C}$ yang termasuk ke dalam tipe temperatur tinggi. Perhitungan ini bertujuan untuk memperkirakan temperatur bawah permukaan yang berhubungan dengan temperatur reservoir. 


\section{MAKALAH ILMIAH}

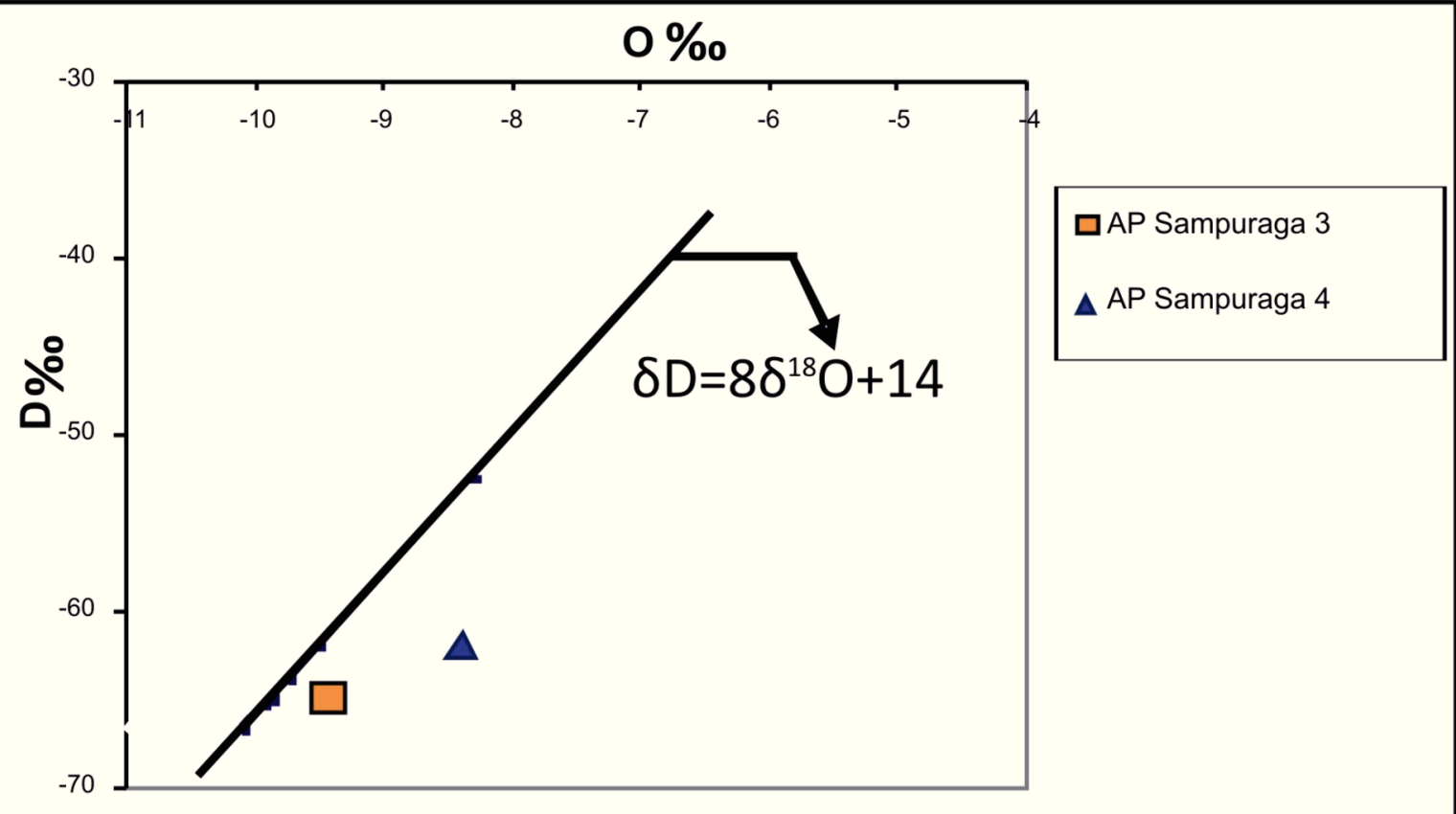

Gambar 10. Ploting Isotop $\delta D$ terhadap $\delta^{18} \mathrm{O}$ Air Panas Bumi Sampuraga

\section{DISKUSI DAN PEMBAHASAN}

Asumsi konsentrasi senyawa kimia terlarut secara kualitatif dan kuantitatif dalam air panas merupakan produk akhir dari proses yang alami. Pada umumnya aliran fluida panas pada temperatur tinggi berinteraksi dalam keseimbangan dengan jenis mineral tertentu pada batuan panas bumi, sehingga memberikan indikasi konsentrasi tinggi untuk senyawa $\mathrm{Si}, \mathrm{Na}$, $\mathrm{K}$ yang erat kaitannya dengan temperatur dan $\mathrm{pH}$ mata air panas yang terukur di lapangan.

Mekanisme pembentukan sinter karbonat yang muncul di sekitar mata air panas disebabkan oleh faktor batuan yang dilalui oleh fluida panas. Batuan penyusun daerah tersebut yaitu sedimen karbonat atau gamping yang kaya dengan mineral $\mathrm{CaCO}_{3}$ ini. Reservoir panas bumi mengubah $\mathrm{pH}$ air panas menjadi netral, yang kemudian melarutkan sebagian kalsium dan karbonatnya, melalui reaksi berikut:

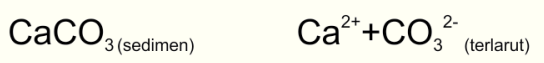

Pada permukaan manifestasi terjadi penurunan temperatur sampai kondisi "flashing atmosphere" yang diikuti pengendapan kembali membentuk sinter karbonat $\left(\mathrm{CaCO}_{3}\right)$, seperti reaksi berikut:

$\mathrm{Ca}^{2+}+\mathrm{CO}_{3}{ }^{2-} \cdot \quad \rightarrow \mathrm{CaCO}_{3 \text { (sinter) }}$

Senyawa kimia pada air panas lainnya mengindikasikan adanya keterkaitan beberapa unsur atau senyawa kimia panas bumi dalam kondisi temperatur dan $\mathrm{pH}$ larutan yang dapat dijelaskan seperti berikut:

a). Mengacu kepada Grasby,dkk (2000), yang telah menjelaskan pengaruh interaksi/kontak fluida panas dengan batuan melibatkan unsu $r$ Natrium dan Kalium, pada kondisi temperatur tinggi dan $\mathrm{pH}$ netral, reaksi kimianya dalam air panas, seperti berikut:

$\mathrm{K}-\mathrm{fe} / \mathrm{spar}+\mathrm{Na}^{+}=$albite $+\mathrm{K}^{+}$

$10 \mathrm{~K}$-beidellite $+3 \mathrm{Na}^{+}=3 \mathrm{~K}^{+}+10 \mathrm{Na}$-beidellite

Air panas di daerah Sampuraga menunjukkan konsentrasi $\mathrm{Na}$ dan $\mathrm{K}$, yang signifikan sesuai dengan reaksi kimia diatas.

b). Chen, dkk(1997), menjelaskan adanya pengaruh Temperatur pada $50^{\circ} \mathrm{C}$ atau lebih pada $\mathrm{pH}$ asam, terhadap kelarutan mineral albite yang reaksi kimianya seperti berikut:

$$
\begin{aligned}
& \mathrm{NaAlSi}{ }_{3} \mathrm{O}_{8}+4 \mathrm{H}^{+}+4 \mathrm{H}_{2} \mathrm{O}^{50^{\circ} \mathrm{C}} \rightarrow \mathrm{Na}^{+}+\mathrm{Al}^{3+}+3 \mathrm{H}_{4} \mathrm{SiO}_{4} \\
& \text { Albite }
\end{aligned}
$$

Reaksi kimia ini sesuai dengan konsentrasi yang tinggi dari $\mathrm{Na}, \mathrm{Al}$, dan $\mathrm{SiO}_{2}$ dalam APS 1.

c). Martin, dkk (2000), menjelaskan terbentuknya kation alumunium, dalam kondisi $\mathrm{pH}$ asam dari senyawa alumina yang mengandung alumunium, melalui mekanisme reaksi yang cukup panjang, seperti berikut: 


\section{MAKALAH ILMIAH}

$$
\begin{aligned}
& 9 \mathrm{KAISi}_{3} \mathrm{O}_{8}+12 \mathrm{H}^{+}+2 \mathrm{SO}_{4}{ }^{2-}+2 \mathrm{H}_{2} \mathrm{O} \rightarrow \mathrm{KAl}_{3}\left(\mathrm{SO}_{4}\right)_{2}(\mathrm{OH})_{6}+3 \mathrm{Al}_{2} \mathrm{Si}_{2} \mathrm{O}_{5}(\mathrm{OH})_{4}+21 \mathrm{SiO}_{2}+8 \mathrm{~K} \\
& \text { Adularia } \rightarrow \text { alunite kaolinite } \\
& 3 \mathrm{Al}_{2} \mathrm{Si}_{2} \mathrm{O}_{5}(\mathrm{OH})_{4}+6 \mathrm{H}^{+}+4 \mathrm{SO}_{4}{ }^{2-}+2 \mathrm{~K}^{+} \rightarrow 2 \mathrm{KAl}_{3}\left(\mathrm{SO}_{4}\right)_{2}(\mathrm{OH})_{2}+6 \mathrm{SiO}_{2}+3 \mathrm{H}_{2} \mathrm{O} \\
& \text { Kaolinite } \rightarrow \text { alunite } \\
& \frac{\mathrm{Al}_{2} \mathrm{Si}_{2} \mathrm{O}_{5}(\mathrm{OH})_{4}}{\text { Kaolinite }}+6 \mathrm{H}^{+}+3 \mathrm{SO}_{4}{ }^{2-}+2 \mathrm{~K}^{+}+16 \mathrm{H}_{2} \mathrm{O} \rightarrow \frac{\mathrm{Al}_{2}\left(\mathrm{SO}_{4}\right)_{3}}{\text { alunogen }} \cdot 17 \mathrm{H}_{2} \mathrm{O}+2 \mathrm{H}_{4} \mathrm{SiO}_{4} \\
& \mathrm{Al}_{2}\left(\mathrm{SO}_{4}\right)_{3} \cdot 17 \mathrm{H}_{2} \mathrm{O}+2 \mathrm{H}_{4} \mathrm{SiO}_{4} \rightarrow 2 \mathrm{Al}^{3+}+3 \mathrm{SO}_{4}{ }^{2-}+2 \mathrm{SiO}_{2}+21 \mathrm{H}_{2} \mathrm{O} \\
& \text { Alunogen }
\end{aligned}
$$

Rangkaian reaksi kimia di atas, juga sesuai dengan kondisi APS 1, yang memiliki pH asam, temperatur tinggi $\left(97^{\circ} \mathrm{C}\right)$, mengandung konsentrasi yang tinggi dari $\mathrm{Al}, \mathrm{SO}_{4}$, dan $\mathrm{SiO}_{2}$. Diperkirakan $\mathrm{pH}$ dan temperatur mengontrol semua mekanisme reaksi kimia yang berlangsung.

\section{KESIMPULAN}

Konsentrasi senyawa kimia terlarut secara kualitatif dan kuantitatif dalam air panas merupakan produk akhir dari proses yang alami. Pada umumnya aliran fluida panas pada temperatur tinggi berinteraksi dalam keseimbangan dengan jenis mineral tertentu pada batuan panas bumi, sehingga memberikan indikasi konsentrasi tinggi untuk senyawa $\mathrm{Si}, \mathrm{Na}$, $\mathrm{K}$ yang erat kaitannya dengan temperatur dan $\mathrm{pH}$ mata air panas yang terukur di lapangan.

Pendugaan suhu reservoir dengan geotermometer yang mencapai $233^{\circ} \mathrm{C}$ menunjukan bahwa sistem panas bumi di daerah Sampuraga memiliki tipe vulkanik upflow entalpi tinggi.

\section{UCAPAN TERIMAKASIH}

Penulis menyampaikan terima kasih kepada Kepala Pusat Sumber Daya Geologi, Pejabat Pembuat Komitmen, dan Koordinator Kelompok Penyelidikan Panas Bumi atas izin yang diberikan untuk penggunaan laporan dalam pembuatan makalah ini.

\section{DAFTAR PUSTAKA}

Aldiss, D.T., Whandoyo, R., Ghazali, S.A. \& Kusyono, 1983. Peta Geologi Lembar Sidikalang dan (sebagian) Sinabang, Sumatra (Geological Map of Sidikalang and Sinabang (part) sheets, Sumatra). Pusat Penelitian dan Pengembangan Geologi, Bandung, Skala 1:250 000.

Chen, Y., and Brantley,S.L., 1997, Temperature- and pH dependence of albite distributrion rate at acid pH. Chemical Geology, V. 135, pp. 275-290.

Giggenbach, W.F., and R.L. Goguel, 1989. Collection and analysis of geothermal and volcanic water and gas discharges [unpublished report]. Petone, New Zealand: Chemistry Division, Department of Scientific and Industrial Research, $81 \mathrm{p}$.

Giggenbach, W.F., 1988, Geothermal Solute Equilibria Deviation of Na-K-Mg-Ca Geo- Indicators, Geochemica Acta 52. pp. 2749-2765.

Grasby, S.E., Hutcheon, I., and Krouse, H.R.,2000, The influence of water-rock interaction on the chemistry of thermal springs in western Canada Applied Geochemistry V. 15, pp.147-154.

Hochstein, M.P. (1990), "Classification and assessment of geothermal resources." In: Dickson MH and Fanelli M (eds) Small geothermal resources, UNITAEWNDP Centre for Small Energy Resources, Rome, Italy, pp. 31-59.

Martin, R., Rodgers, K.A., and Browne, P.R.L., 2000, Aspects of the distribution and movement of alumunium in the surface of the Te Kopia geothermal field Taupo Volcanic Zone, New Zealand, Applied Geochemistry, V. 15, pp.1121-1136. 